\title{
7.1.0. MULTILINGUALISM IN PAPUA NEW GUINEA ${ }^{1}$ Gillian Sankoff
}

\begin{abstract}
Editor's Note: The contents of this chapter is very largely based on information extant in 1972-73. Particularly in view of its extensive use of 1966 census data using 'district' divisions, it has been decided to leave references to 'districts' unchanged and not to alter them to 'provinces' to reflect current usage in 1977.

Though it is an incontrovertible fact that the nature of $b 1-$ and multilingualism ${ }^{2}$ is changing very rapidly in Papua New Guinea, it is certainly not the case that this is a phenomenon unique to the colonial and Independence periods of Papua New Guinea history. Indeed, in order to appreciate the phenomenon of multilingualism in the present day, it is necessary to attempt the best possible reconstruction of the degree and nature of multilingualism in the precolonial period.
\end{abstract}

\subsubsection{MULTILINGUALISM IN THE PRECOLONIAL PERIOD}

\subsubsection{LANGUAGE DISTRIBUTION AND ITS IMPLICATIONS FOR MULTILINGUALISM}

The approximate number of languages, the relative distribution of Austronesian and non-Austronesian (Papuan) languages, and the implications of this distribution in reflecting prehistoric relationships and migrations, have been dealt with extensively in chapters of vols $I$ and II (Wurm, ed. 1975, 1976), as well as in works such as Capell 1969, 1971; Chowning 1970; Dutton 1969; Healey 1964; Hooley and McElhanon 1970; Laycock 1965; Wurm 1960, 1971a; Wurm and Laycock 1961; Z'graggen 1971; and the many detalled studies in McKaughan 1973. Various kinds of language contact in the New Guinea area, with particular reference to contacts between speakers of Austronesian and Papuan languages, have been given by Laycock (1973). Our main concern here, however, is the implication of such diversity for multilingualism. 


\subsection{Very Small Languages}

Of the probably 700 or more languages of Papua New Guinea, it is likely that over a third have (and have had, for some time) an extremely small number of speakers. 'Extremely small' here means less than 500 speakers. This approximation is based (for Papuan languages) on data presented by Wurm (1971a) in the most complete survey of Papuan languages to date (until the publication of vol.I (Wurm, ed. 1975)). Eliminating several of his groupings which fall largely in Irian Jaya, we are left with approximately 449 languages, of which 169 have less than 500 speakers, as shown in Table 1. Though we have no such complete statistics, analogous to Wurm's, for the Austronesian languages of Papua New Guinea, data culled from Hooley and McElhanon 1970 on 37 Austronesian languages of the Morobe District, from Beaumont 1972 on 20 New Ireland Austronesian languages as well as the Tolal language of New Britain, ${ }^{3}$ from Z'graggen 1971 and Claassen and McElhanon 1970 on 14 Madang District Austronesian languages, and from Dutton 1970a, 1971 on 12 Austronesian languages of south-eastern Papua, tend to show a similar pattern. Of these 84 Austronesian languages, 21 have less than 500 speakers, as is also shown in Table 1. Thus of the 533 languages of Papua New Guinea for which statistics on the number of speakers have been compiled in Table 1, we find that 190, or 35.6\%, have fewer than 500 speakers.

Most of the speakers of these very small languages are (and probably were in the past) bilingual or multilingual, according to evidence from recent language surveys. Laycock (1965), for example, discussing the two smallest members of the Ndu language family of the East and West Sepik Districts, has this to say (p.131):

Ngala is spoken by the 134 inhabitants of a single village, Swagup, [which] ... lies off the Sepik River, several hours' travel up a narrow tributary stream. The nearest speakers of an Ndu-family language are the Iatmul-speaking inhabitants of Brugnowi, with whom however the people of Swagup have till recently had a long-standing feud .... It is with the Wogamusin-speaking inhabitants of Washkuk that the swagup natives have most of their trading contacts ... a large number of adult males in Swagup speak Wogamusin ....

(It should be noted that Wogamusin, a non-Ndu Papuan language, itself has only 336 speakers, which 1s, however, more than double the number of Ngala speakers.) Laycock continues:

Yelogu is spoken by the inhabitants of a single village ... All 63 inhabitants appear to be bilingual, speaking the unrelated Kwoma language as well as Yelogu. (Laycock 1965:139)

No such bilingualism is reported for the four other languages of the Ndu Family, all of which number well over 1,000 speakers. 
TABLE $]$

Distribution of the Number of Speakers of 533 Papuan and Austronesian Languages in Papua New Guinea

\begin{tabular}{|c|c|c|c|c|c|c|c|c|}
\hline \multirow{3}{*}{$\begin{array}{c}\text { Speakers } \\
\text { per language } \\
30,000+\end{array}$} & \multicolumn{3}{|c|}{ PAPUAN LANGUAGES* } & \multicolumn{3}{|c|}{ AUSTRONESIAN LANGUAGES * * } & \multicolumn{2}{|r|}{ TOTAL } \\
\hline & & $\begin{array}{l}\text { of } \\
\text { gguages }\end{array}$ & $\begin{array}{l}\text { Approx. total } \\
\text { population }\end{array}$ & $\begin{array}{r}\text { No } \\
\text { lanc }\end{array}$ & $\begin{array}{l}\text { of } \\
\text { juages }\end{array}$ & $\begin{array}{l}\text { Approx. total } \\
\text { population }\end{array}$ & $\begin{array}{l}\text { No. of } \\
\text { languages }\end{array}$ & $\begin{array}{l}\text { Approx. total } \\
\text { population }\end{array}$ \\
\hline & $9^{+}$ & $(2.2 \%)$ & $460,000(31.4 \%)$ & $1^{++}$ & $(1.2 \%)$ & $30,000(15.1 \%)$ & $10 \quad(1.9 \%)$ & $490,000(29.4 \%)$ \\
\hline $10,000-29,999$ & 22 & $(4.9 \%)$ & $385,000(26.3 \%)$ & 3 & $(3.6 \%)$ & $31,500(15.8 \%)$ & $25(4.7 \%)$ & $416,000(25.0 \%)$ \\
\hline $5,000-9,999$ & 38 & $(8.5 \%)$ & $265,000(18.1 \%)$ & 6 & $(7.1 \%)$ & $39,300(19.7 \%)$ & $44 \quad(8.3 \%)$ & $304,300(18.5 \%)$ \\
\hline $1,000-4,999$ & 135 & $(30.1 \%)$ & $274,000(18.7 \%)$ & 38 & $(45.2 \%)$ & $83,700(42.0 \%)$ & $173(32.5 \%)$ & $357,700(21.5 \%)$ \\
\hline $500-999$ & 76 & $(16.9 \%)$ & $48,500 \quad(3.3 \%)$ & 15 & $(17.9 \%)$ & $9,800 \quad(4.9 \%)$ & $91(17.1 \%)$ & $58,300 \quad(3.5 \%)$ \\
\hline less than 500 & 169 & $(37.6 \%)$ & $33,500 \quad(2.3 \%)$ & 21 & $(25.0 \%)$ & $5,000 \quad(2.5 \%)$ & $190(35.6 \%)$ & $38,500 \quad(2.3 \%)$ \\
\hline TOTAL & 449 & & , 466,000 & 84 & & 199,300 & 533 & $1,665,300$ \\
\hline
\end{tabular}

*Data on Papuan languages abstracted from Wurm 1971.

* Data on Austronesian languages abstracted from Hooley and McElhanon 1970; Beaumont 1972; Z'graggen 1971; Claassen and McElhanon 1970; Dutton 1970a, 1971.

N.B. This table is not complete, particularly with respect to Austronesian languages. Information contained in Wurm, ed. 1976, unavailable to me before the present chapter went to press, will be invaluable in revising and completing this table.

+The 9 languages are Enga - 110,000; Medlpa - 60,000; Chimbu - 60,000; Hul1 - 54,000; Kewa - 39,500; Kamano - 38,500; Wahgl - 37,000; Gawigl - 31,000; Mendi - 30,000.

${ }^{+}$The Austronesian language in question is Tolai. 
In a study of the languages of the Finisterre Range, Claassen and McElhanon (1970) make such observations concerning a number of the very small languages of that area. For example, discussing the Erap Family of the Morobe District, they state (p.56):

The Mamaa language is spoken in the village of Mamaa (pop.200) on the east bank of the lower Irumu River. With the exception of the Finungwan language, this language shows no lexicostatistical relationship greater than $35 \%$ with the other languages in the family. The $46 \%$ relationship with Finungwan may reflect borrowings since the people are being assimilated by the Finungwan people and most of them are bilingual.

In a close parallel with the Ngala-speakers of Wogamusin cited by Laycock, we note that the Finungwan language, like Wogamusin, is itself very small, numbering only 400 speakers, but again double the number of speakers of Mamaa.

A further case cited by Claassen and McElhanon (1970) is that of speakers of the Yabong language of the Yaganon Family in the Madang District (p.61):

The Yabong language (pop.370) is spoken in five villages west of the Yangda River .... Many of the people are

reported to be fluent in the Rawa language.

(Note that Rawa is an only very distantly related, fairly large language of 6,000 speakers belonging to the Finisterre Stock, whereas Yabong belongs to the Rai Coast Stock.)

Parallel evidence is presented in studies of other very small languages, many of which tend to occur in border areas between larger language groups, often as a result of the drastic reduction of a population through warfare or disease. Such a situation is discussed for the Binumarien (three small villages in the Kainantu Sub-District of the Eastern Highlands District, very near the Morobe District border, and containing a total of 117 people) by Oatridge and Oatridge (1973: 517 ):

The Binumarien are a very small group. Within the memory of the older men, they were more numerous, but because of tribal fighting resulting in prolonged residence in the Markham Valley and resultant malaria, their numbers have been greatly reduced. Their neighbors to the west and south are the Gadsup, and to the north the Azera in the Markham Valley. The closely related language of Kambaira is in the southeast. The Binumarien are most closely related to the Tairora though some of the men speak Azera and Gadsup while others speak Gadsup and Tairora as well as their own language.

Though I have rather conservatively restricted the 'very small' language category to those numbering less than 500 speakers, it is very likely that many speakers of slightly larger languages, numbering, say, up to 1,000, were also bilingual. Bee (1965:39-40) describes such a situation for the Usarufa: 


\begin{abstract}
Usarufa [is] a language spoken by approximately 850 persons in the Eastern Highlands District ... The Usarufa-speaking area is located in a pocket surrounded by Kamano, Kanite, Fore, and a small segment of Auyana speakers. All of these languages except the Auyana have been classified by Wurm as members of language families distinct from Usarufa. Nevertheless most adult Usarufa speakers speak at least one of the three more distantly related languages and many speak all

three. Contrariwise very few Fore, Kamano or Kanite speakers are able to speak Usarufa. Also of note is the fact that... few Usarufa speakers admit to speaking or understanding

Auyana which is so closely related that the two may be dialects of one language.
\end{abstract}

This is confirmed by Berndt (1954:291) who notes also that 'nearly all' of the Usarufa 'seem to have some knowledge of Jate'. The Jate (or Yate, population 3,988 according to Wurm (1971a)) lie immediately to the west of the Usarufa, 'In some cases only 15-20 minutes' walk away' (Berndt 1954:291).

The quotation from Laycock 1965 cited above suggests one reason for speakers of such small languages to be bilingual, 1.e. trading contacts, necessarily (especially when the language is confined to a single village or hamlet) with speakers of other languages. Another type of contact, even more important for fostering bilingualism in such cases was inter-marriage, again a virtual necessity for members of very small language groups. This meant that a large number of women brought up in such a small language group would, upon marrying outside of 1 , find themselves to be in a linguistically foreign environment for their married lives; and that men brought up in such groups would very likely bring in wives who did not initially speak the group's language, which in turn would expose their children to more than one language.

Note that in all of the citations above, either no sex difference in bilingualism is noted or else special note is taken that men are bilingual. It is unlikely that this reflects a real sex difference in bilingualism; rather, given that in such small language groups a large proportion of the adult women will be married in from other language groups and therefore not be native speakers of the language groups in which they now live, they are of little or no interest to a linguist whose main job is finding out about the language of the group in question, and therefore will not perhaps notice that these women are also bilingual. 4

\title{
7.1.1.1.2. Trade Languages in Coastal Areas
}

Though as is indicated in Table 1, speakers of somewhat over a third of the languages of Papua New Guinea were probably obliged by demography alone to become bilingual, it is also clear from this table that such 
speakers never constituted more than a tiny minority of the total population. Even if we include the next smallest group of languages, those having between 500 and 1,000 speakers, not more than 6\% of the population would be included in this category (though the two groups constitute fust over half the languages!).

We now turn to an examination of the case of the great majority of Papua New Guineans, that $94 \%$ of the population not living in language isolates, and whose language groups consist of over 1,000 speakers. Though data relevant to multilingualism are very incomplete for these larger language groups, we can, I feel, plece together a general picture with respect to multilingualism among speakers of any such languages. Though it is obvious that the larger the number of speakers of any particular language, the less likely would contacts such as trade and intermarriage be necessary with speakers of other languages, there is still considerable evidence indicating varying degrees and types of competence in other languages and dialects among many speakers of such languages.

First, note in Table 1 given in 7.1.1.1.1. that the distribution of speakers differs between Papuan and Austronesian languages. The bulk of the speakers of the 84 Austronesian languages in Table 1, 1.e. 42\%, are concentrated in languages having between 1,000 and 5,000 speakers. As is well known, most of these languages (as well as many Papuan languages of similar medium size) are located in coastal areas, where trade circuits of considerable size operated in the past.

In many coastal areas, the language of one of the trading groups, sometimes in a somewhat simplified version, was used as a lingua franca throughout the trade circuit in question. A very famous case is that of Hiri Motu (also known as Police Motu), the language

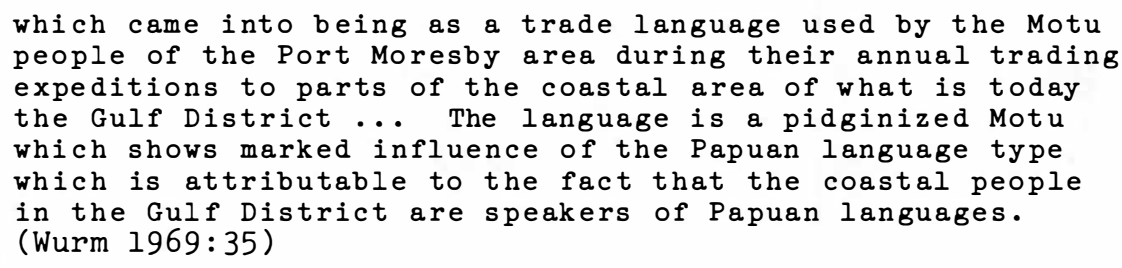

As early as the beginning of the 20th century, 'the fact that the Motu and the various Gulf tribes visited by them make use of a common trading dialect which is in some measure distinct from the very widely divergent languages of either' (Barton 1910:96) ${ }^{5}$ was cited as evidence that such trade had 'existed for a very considerable period' (p.96). Thus bilingualism in their own language and Hiri Motu existed among members of those groups who traded with the Motu-speakers well before the beginning of the colonial period. This language was used by the Motuans and 
their trade partners both on the Motuans' visits to the Papuan Gulf, and on return visits by the peoples of the Gulf, as described by Eri $(1970: 35)$. Speakers of Kolta have also been bilingual in Motu for a very long time:

The Koita are a tribe speaking a Papuan language who have for generations intermarried with the Motu and whose villages are usually built near, or even in direct contiguity with those of the Motu. Although the Koita still speak a Papuan language the majority of the males speak Motu, a Melanesian language... (Seligman 1910:16)

Later Seligman goes on to say that 'practically all the Kolta speak Motu' (p.45).

In another well-known trade clrcuit, that of the Kula, it appears that Dobuan was the lingua franca. Writing of the period between 1914 and 1918, Malinowski states:

It is characteristic of the international position of the Dobuans that their language is spoken as a lingua franca all over the d'Entrecasteaux Archipelago, in the Amphletts, and as far north as the Trobriands. In the southern part of these latter islands, almost everyone speaks Dobuan, although in Dobu the language of the Trobriands or Kiriwinian is hardly spoken by anyone. (Malinowski 1966:39-40)

Malinowski mentions this fact mainly because he finds it a curlous one, his feeling being that Kiriwinian, as the language of the more numerous and equally prestigious Trobrianders, would have been a more likely choice for a lingua franca. In describing the trade visits of the Trobrianders in Dobu, Malinowski again remarks on the use of Dobuan. He says:

In the villages, they are entertained by their male friends, the language spoken by both parties being that of Dobu, which differs completely from Kiriwinian, but which the Sinaketans learn in early youth. (Malinowski 1966:364)

Despite the widespread use of Dobuan, it appears that the Trobrianders did use their own language on visits to certain other islands. The fact that

the natives of the eastern islands, from Kitava to Woodlark, ... speak the same language with dialectical differences only ... (Malinowski 1966:478)

is sald by Malinowski to have facllitated trade between the Trobrianders and the people of these islands. He also describes (p.270) a trade visit in the Amphletts in which Kiriwinian was the language used.

Farther west along the northern coast of Papua New Guinea, bilingualism in the language of traders appears to have existed in two other areas: the northern coast of the Huon Peninsula, and the Huon Gulf area. According to Harding (1967:203):

Sio informants say that communication was based on a pidgin form of the Siassi language (tok Siassi haphap), a trade lingo 
with a Siassi vocabulary which was useful not only in meetings with the Siassis themselves, but with other island and coastal peoples.

Slightly further south, in the Huon Gulf area,

It seems that in the past the pot makers from the south, the basket weavers from Labu, and the Tami Islanders all made a practice of learning Gawa (or Kawa), the vernacular spoken on the North Coast and around Busama. (Hogbin 1947:247)

This sample of four regional trading languages certainly does not exhaust the total coastal area of Papua New Guinea; nevertheless, these four alone were spoken as a second language by thousands of people speaking many languages, both Papuan and Austronesian, along hundreds of miles of coastilne. In addition, similar situations probably existed in many other coastal areas on which I have not been able to locate any data. Unlike the bilingual speakers of the very small languages discussed in 7.1.1.1.1., people bilingual in their own language and one of the coastal trade languages appear not to have been so likely to be also intermarried with speakers of these languages. 6 Trading voyages involved the traders being entertained, each by his own trade friend in a foreign port, for falrly short periods on any one trip, 1.e. not more than a couple of weeks at a time. The traders were men, and were on their trips apparently engaged in talk principally with other men in the language groups they visited. This probably means that unlike the situation in very small languages, there was a sex bias in favour of men with respect to bilingualism in the villages visited by traders. It also seems likely that few men or women who were native speakers of the lingua franca were bilingual, as Malinowski specifically states for the Dobuans. (If Barton is correct in his statement that the Motu spoken as a contact language was indeed quite different from Motu, then the Motuan traders could be sald to have been 'bilingual' and form an exception to the pattern of speakers of languages like Dobuan.)

In an article George Grace kindly brought to my attention when this chapter was completed, Schlesier (1961) discusses the impact of 'trade friend' relationships on bilingualism in various parts of New Guinea, citing missionary and other sources dating from the 1890s. He stresses the often lengthy period of time spent by youths in their fathers' trade friends' villages, during which visits language learning was a major goal.

\subsection{Inland Middle-Range Languages}

Section 7.1.1.1.2. has dealt with the middle-range languages of the coast, mainly Austronesian though including some Papuan languages (it is of note that the four trade languages discussed in 7.1.1.1.2. In 
which both Austronesian and Papuan speakers were bilingual, are all themselves Austronesian). But the bulk of speakers of the middle-range Papuan languages are to be found inland.

Here again, the situation appears to be a result of the interaction between demography (1tself a result of the nature of the terrain and of historical forces in shaping migration patterns) and socially regulated patterns of trade and intermarriage. But even more than in preceding sections, we are severely hampered by lack of information; very few ethnographies or linguistic surveys have paid much attention to bilingualism. Very roughly, it appears that there has existed a fair amount of bilingualism in border areas and among the smaller, or more isolated segments of any linguistic group, but that multilingualism is unlikely in the central areas of large linguistic groups.

The most detailed account of multilingualism in a middle-range Papuan language is Salisbury's (1962) description of the Siane, located in the border areas of the Chimbu and Eastern Highlands Districts southeast of Chuave. Siane, which according to Wurm (1971a:549) numbers approximately 15,336 speakers, is the westernmost member of the EastCentral Family of the East New Guinea Highlands Stock. Salisbury documents a very high degree of bilingualism on the part of Siane-speakers in 'various of the Dene dialects' (Salisbury 1962:2). (Note that 'Dene' is regarded by Wurm (1971a) as two languages: Chuave (population 5,639) and Nomane (population 2,502), belonging to the Central Family of the East New Guinea Highlands Stock.) Salisbury, who lived in a village where the language spoken was the Komunku dialect of Siane, states that

Conversations among the residents could often be trilingual, a Ramfau [note: Ramfau is another dialect of Siane] wife speaking Ramfau to her son who replied in Komunku and who was supported by his wife speaking in Dene. (Salisbury 1962:2) Salisbury (1962) reports that in informal situations among groups of bilinguals, each would speak 'whatever language was easiest for them' (p.3) with no translation occurring, whereas in formal situations, 'each formal speech would be followed immediately by a translation of it into the other language' (p.3). Some Komunku speakers would use Dene on formal occasions, speaking Komunku on informal ones, an indication of the high prestige of multilingualism among the Siane (pp.4-5). Salisbury also mentions that whereas Komunku dialect speakers in the western area tended to be fluent in Dene, many of those in the east also knew Gahuku.

Salisbury's interesting and provocative account raises a number of questions about bilingualism from a qualitative point of view, questions involving such difficult problems as active versus passive bilingualism 
(in conversations where each speaks his 'easiest' language and listeners appear to understand), the issues of whether a linguistic boundary constitutes a language or dialect difference, and of the relative prestige (or lack of $1 t$ ) of bilingualism. As these issues will be discussed in 7.1.1.2. below, let it suffice to mention here that the relatively large size of the Siane language does not appear to have impeded a fair amount of bilingualism among its speakers, at least those in border areas. The fact that the Siane live in a very densely populated area and are surrounded on all sides by other language groups is probably one of the reasons for this; another, very important, reason is that the Siane traditionally did not appear to regard speaking Siane as a basis for any type of political identity. Salisbury is quite explicit that (as of 1952-53) they had

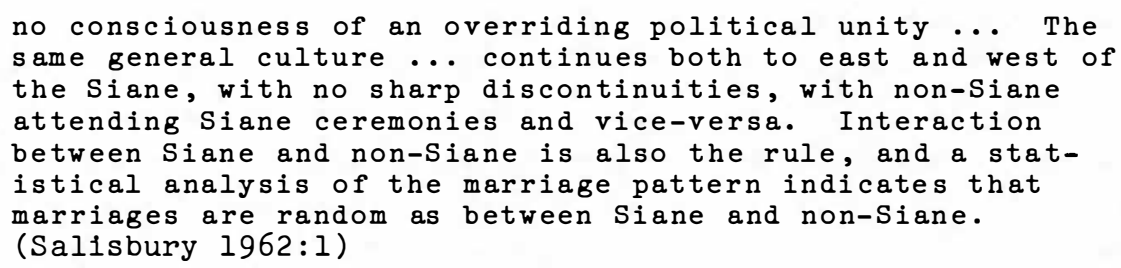

Other ethnographers working in various inland areas of Papua New Guinea have also noticed multilingualism in border areas between middlerange languages. Harding, discussing the interior of the Huon Peninsula in the Morobe District, speaks of:

an area of intergrading, ... known by the indigenous people as the 'head' of the Komba, Selepet and Timbe peoples.

Linguistically, the area is mainly Komba, but the Timbe and Selepet are close at hand and there is a marked degree of multilingualism. (Harding 1965:199)

It should be noted that the population figures given for these three Papuan languages of the Huon Micro-Phylum (now (Wurm, ed. 1975): Huon Stock) are 10,000 speakers each for Komba and Timbe, and 5,500 for Selepet (Hooley and McElhanon 1970:1082).

Rappaport, discussing the Maring (population 4,500 according to Wurm 1971a:550), states that four of the 50 married women and widows living in the Maring local group of 200 which he studied in 1962-63 'came from nearby Karam-speaking groups' (Rappaport 1967:102). Karam (population 10,000-14,000) belongs to a family quite distant from Maring with which it shares only '19\% basic vocabulary cognates' (Wurm 1971a:

553). Rappaport (1967:102, n.2) also states that

marriage between Jimi Valley Maring and Narak speakers is frequent. It may be that propinquity, rather than linguistic affiliation, is the decisive factor in intergroup marriage. 
Though the status of Narak has been somewhat disputed in the literature, Cook (1966:442) affirms that both according to its degree of cognation with Maring (only 57\%) and according to the views of Maring- and Narakspeakers, Maring and Narak are separate languages. Wurm (1971a:550) concurs with this view, listing Narak as a separate language with approximately 4,500 speakers. Though Rappaport does not draw any conclusion on bilingualism from his intermarriage data, we can conclude that wives from both Karam and Narak would probably have become bilingual in Maring upon marrying into that language group, and that maintaining affinal relations among the various groups probably also made for a certain amount of bilingualism among the men as well.

Taking one further example of a middle-range Papuan-speaking group in the Highlands, Wagner (1969) has this to say about the Daribi, of the extreme south of the Chimbu District:

Approximately 3000 Daribi live on the volcanic plateau north of Mt. Karimui and in the adjacent limestone country to the west; they have intermarried extensively with a pocket of 1000 Tudawe (=Pawaia) speakers living northeast of the mountain. (Wagner 1969:56)

According to Wurm (1971a), the Mikaru-speaking Daribi number approximately 4,000, and the Pawaia, who belong to a different family, somewhat under 2,000 (Wurm 1971a:551).

There is a certain amount of evidence that where large and small groups were in contact, it was generally the members of the small group or isolate who became bilingual, though some of the members of the larger linguistic groups also found it advantageous (or necessary) to learn the others' language. Among the larger groups nelghbouring the Usarufa discussed in 7.1.1.1.1., Berndt (1954:291) remarks that:

bilingualism ... is much more common in the border districts than in those which have rather less frequent contact with people speaking languages other than their own ... Members of the three larger language units rarely trouble to learn Uturupa ( = Usurufa), except in matters involving continued personal contact - such as, especially, alien women married to Uturupa men.

Nevertheless it seems that a considerable number of foreign women did marry into Usarufa, as is shown in the following quotation:

Kemiju (Yate), Moiife (Usurufa), Ofafina and Asafina (Fore) are bitter enemies of Kogu (Usurufa), but they are also its main source of wives as well as its guests for certain festivals, ceremonies, and so on. They comprise the principal units in the zone of most intensive interaction centering on Kogu ... they are engaged jointly in so many transactions, ... they come in contact with one another fairly regularly and are dependent on one another, and ... their territories adjoin. (Berndt 1962:234) 
It also appears that in this border area, the larger groups also knew each other's languages to some extent. Berndt mentions that in three border villages of the Fore, 'the Fore language predominates, with some Jate' (Berndt 1962:8).

The five multilingual situations discussed in this section have all involved linguistic groups of the middle range, numbering between about 2,500 (Nomane, in the Siane example), and 15,000 (Siane itself). In addition, all five have involved border areas, in four of which intermarriage has been specifically mentioned. Both Salisbury and Rappaport stress the lack of political unity or common identity within the language group, and the fact that linguistic differences do not seem to constitute a barrier to intermarriage. One is left with the distinct impression that this is a situation common to many, if not most, Iinguistic border areas in the Highlands. As we shall see below in 7.1.1.1.4., this situation can indeed be generalised to at least three of the nine 'large languages' of the Highlands.

\subsection{Large Languages of the Highlands}

Though monolinguals in the central areas of the large language groups (those numbering over 30,000 in Table 1 given in 7.1.1.1.1.) are likely to be much more numerous than those living in the central areas of the smaller language groups we have so far been discussing, the phenomenon of multilingualism in border areas appears to be just as true for these groups as for the smaller ones. Brookfield and Brown have this to say about the Chimbu, which with 60,000 speakers is probably the second or third largest language group in Papua New Guinea:

The high mountains which enclose the Chimbus to the east,
north, and north-west have not proved a barrier to trade,
migration, and marriage. To the east are Asaro speaking
people, . . in another language family. For the last three
generations at least, the Chimbus have intermarried with
Asaro people near Mirima and Korfena, and about 350 have
established villages on land which they acquired from their
affines. Yonggamugl Chimbus have migrated eastward to
establish villages among Siane-speaking people, .. with
whom they intermarry. To the north-east, the Chimbus have
similar relations with the Bundi (Gende) people. In these
cases visiting and ceremonial activities continue with the
people of the chimbu Valley. (Brookfleld and Brown 1963:78)

Not only Asaro (population 11,597) but also Gende (population 8,000) and Siane (population 15,336) are in a family different from that of Chimbu. And the situation (intermarriage, visiting for ceremonials) sounds very similar to that described by Salisbury. On this basis, we are justified in postulating a certain amount of multilingualism, at least (conservatively) among those who are actually intermarried with 
members of other language groups, and probably extending to a majority of those in border villages.

Brookfield and Brown (1963) go on to discuss relationships with the Chimbu's neighbours to the south-east, south, and west, with whom linguistic and cultural ties are 'much closer' (p.78) than those with the Asaro, Gende, and Siane. On the Wahg1, to the west of Chimbu, they say:

At the border of Chimbu and Wahgi, territories have interpenetrated, intermarriage is common, and languages, which belong to different sub-families, are mutually understood by the frontier groups. (Brookfield and Brown 1963:78)

According to Wurm (1964), such cases of bilingualism at the borders of large languages were not at all uncommon. He says:

The spreading of large languages is progressing at the present day, and the widespread bilingualism is one of the means by which one language gradually supersedes another ... This may lead to the gradual extinction of small languages ...

(Wurm 1964:97)

Our second case of language contact in the border area of a large language group is that of the Hull, as described by Glasse (1968). In describing Huli relationships with their neighbours, Glasse does not appear to feel there is much contact. He states that the Huli (population 54,000 according to Wurm 1971a:551) 'exchange visits and occasionally intermarry' (Glasse 1968:20) with the Waga, the Dugube, the Ipili (population 4,500 according to Wurm 1971a:550) and the Duna (population 6,000 according to Wurm 1971a:551). Nevertheless he comments in discussing the geographical extension of Huli that 'just where the dividing line - or zone of transition - between Huli and Duna culture is to be found, was still uncertain in 1959' (Glasse 1968:18). The reason for construing the border area as a 'zone or transition' appears in a chance remark regarding the location of the patrol post at Koroba, 'In a bilingual area where Hull and Duna are both spoken' (p.18). It is of note that Duna is the most distantly related language of any of the Huli's neighbours, being in a different family and showing only 25\% cognates with Hull according to Wurm (1971a:557). The Huli-Duna border area is one of the very few areas where two languages are shown as overlapping on Wurm's (1961) map of the Highlands languages.

Lastly, Strathern (1972) gives some evidence regarding the Medlpa (our second largest Papuan language, at 60,000) of the Mount Hagen area in the Western Highlands. She says (pp.3-4):

North of the Gumant (River) people speak Melpa almost exclusively, while to the south many understand both Melpa and the closely related Temboka (a dialect of Gawigl) ... Warfare, group expansions and migrations in the recent past had led to the intermingling of Temboka and Melpa groups in the immediate vicinity of the present town. 
Summarising very briefly, it is clear that though only a minority of the speakers of the large Highlands languages had occasion to become bi- or multilingual, this was a common phenomenon whose incidence was principally dictated by demography. Language differences were not in and of themselves considered as barriers to communication.

\subsubsection{QUALITATIVE ASPECTS OF MULTILINGUALISM IN THE LANGUAGES OF PAPUA NEW GUINEA}

7.1.1.2.1. Languages, Dialects, Intelligibility and Passive Bilingualism

Finishing our discussion of language distribution with the 'large' languages of the Highlands has perhaps given a false impression of less linguistic diversity than actually exists. For even in these large languages, there was no linguistic homogeneity across all 30,000 or 50,000 speakers, and as has been attested to in 7.1.1.1., speakers did not recognise or often even know of the existence of such large linguistic groups. Instead, the situation was, and is, one of a multiplicity of speech varieties, many of which are very difficult to classify as between languages and dialects. From the point of view of linguistic identity of a particular speaker or group of speakers, and even sometimes from the point of view of intelligibility, two speech varieties which seem to diverge only at the 'dialect' level will count as separate languages.

An example of this was illustrated in an earlier paper of mine discussing Buang dialects (Sankoff 1969), which are related in the chaindialect form common throughout New Guinea, and are located along the Snake River Valley in the Morobe District south of Lae. A comprehension test on three Buang speech varieties: A (headwaters); B (central) and $C$ (lower) was administered to a sample of people in two A villages, three $B$ villages, and two C villages. Lexicostatistic relationships showed $A$ and $B$ to be much more closely related than either to $C$, $A$ to $B$ falling between $77 \%$ and $83 \%$ cognates, depending on the pairs of villages compared; A to $C$ falling between $60 \%$ and $65 \%$, and $B$ to $C$ falling between $66 \%$ and $69 \% .7$ Thus $A$ and $B$ could be considered to be related at the dialect level, whereas $C$ would be consldered a separate language. Nevertheless, in one B-speaking village near the $\mathrm{C}$ border, people found it more difficult to understand tape-recorded stories in the closely related $A$ than in the more distantly related (but geographically close) variety $C$. This would then qualify as a case of bilingualism, albeit passive bilingualism, as the contact situation was such that any meeting between A, B, or C speakers involved each speaking his or her own speech 
varlety and the others understanding. The only people to become actively rather than passively bilingual in one of the speech varieties other than their native variety were in-married other-dialect women, however these constituted a very small proportion of the population. In seven villages where there were approximately 670 married women, only 27 were from other dialects, 1.e. approximately $4 \%$ of the married women. Most of the A, B and C speakers with whom I spoke did not recognise that $C$ was more different from $A$ and $B$, though they all recognised the three major divisions.

Though Buang is unusual in being one of the few inland Austronesian language groups, the sociolinguistic situation involving chain dialects and languages, more intelligibility and heightened cognate percentages at dialect or language borders, and much passive bilingualism, is found all over Papua New Guinea in the distribution particularly of the Papuan languages. The most detailed and comprehensive study of chain relationships is Dutton 1969. Dutton uses the complex relationships among the languages and dialects of the Kolarian language family as an aid in reconstructing the history and patterns of migration of the Kolarian-speaking peoples. Dutton's careful work shows that five of the six Kolarian languages ${ }^{8}$ have numerous dialects, and in all six of the languages, virtually every village is to some extent distinguishable in 1ts speech from others sharing the same 'dialect'. For example, Mountain Kolari, with a population of approximately 3,700, is divided into six dialects, of which Dutton's remarks on the Southern Dialect (population 347, spread among six villages) are illustrative of the general state of relationsips in language-dialect chain relationships (Dutton 1969:49):

This is a small dialect ... markedly different from its northern and western counterparts sharing only an average of 68-76\% basic vocabulary with its nearest neighbour, the Central Dialect. Normally this degree of lexical relationship would be considered too low for a dialect-level relationship. However, since the grammatical structure of the Southern Dialect is very much akin to the rest of Mountain Koiari it is here regarded as merely a divergent dialect of this language rather than a separate, though very closely related, language. Part of the reason for its low lexical relationship with the Central Dialect probably lies in the fact that it is in close contact with Koiari and Barai to the south and east.

Lexically and phonologically the Southern Dialect is also divergent within itself. Thus, at Naoro, villagers living on opposite sides of the village 'street' speak quite differently from one another.

That this situation is also typical of the large languages of the Highlands has been recognised since Wurm and Laycock's classic article 
on language and dialect (1961), in which they discussed speech varieties of the East New Guinea Highlands Phylum sharing cognate percentages of between $60 \%$ and $80 \%$. They noted a tendency towards greater mutual intelligibility among speech varieties in the 70\%-80\% range, but also warned that such 'intelligibility' can be due in part to such 'speakerrelated' factors as pasive bilingualism and the subject of the discourse.

As an illustration of the 'dialect' diversity which exists even in the very largest Papuan languages, we shall consider the case of Kewa, on which we are fortunate in having a very detalled dialect study (Franklin 1968). Franklin gives 39,453 as a conservative population estimate for Kewa (p.9), making it the fifth largest of the Papuan languages listed in Table 1. Franklin (1968:9) distinguishes three major dialects of Kewa: West (population 17,921), East (population 17,758), and South (population 3,774). These can, however, be further subdivided, as the West dialect contains a sub-dialect referred to as North-western (population 6,864), and the South dialect contains a subdialect called South-eastern (population 404). In addition,

There are 3,652 speakers located on the putative boundary of the East and South, all of which are classed as East Dialect speakers. This line actually represents an imagined transition zone between the two dialects. (Franklin 1968:9)

Counting the two sub-dialects and the transition zone, we now have Kewa divided into six speech varieties. But Franklin (1968:1) also notes that:

there is a great deal of regionalism within the language so that few clans ever speak exactly the same as their neighbours ... This is often reflected in their mimicry of how a group nearby speaks, ... For example, if such a nearby group has vowel nasalisation and the focal group does not, the latter will deliberately nasalise all vowels, showing their recognition (in some sense) of one point of difference.

Maps showing isoglosses and distribution of particular lexical items confirm this picture of ordered, but marked, diversity.

Many other authors confirm the fact that virtually all over Papua New Guinea, people pay very great attention to small linguistic differences in differentiating themselves from their neighbours. In addition to Franklin's observations for the Kewa of the Southern Highlands, we have very similar statements from Cook (1966), discussing the relationships of Narak (Western Highlands) with its neighbours. He says:

Many natives of these small speech communities are extremely sensitive to even the most minor of dialect differences and, within a limited spatial range, a perceptive informant can tell you almost precisely in which village an individual was raised as a child. Dialect variations constitute one source of humour, and the speech of natives from slightly or greatly varying speech communities is often the subject of exaggerated mimicry by local inhabitants. (Cook 1966:442) 
Z'graggen (1971:passim) frequently mentions the accuracy of speakers' identification of differences, in his survey of Madang District languages. For example, regarding the inhabitants of Gumalu village, he says: 'informants insisted on having their own distinct language, although a high degree of mutual intelligibility was admitted' (Z'graggen 1971:26). Further on, he continues:

All my informants insisted, even after repeated inquiries, that there was a considerable difference between Yoidik and its neighbours, but they admitted that there was a high degree of mutual intelligibility. (Z'graggen 1971:27)

As a last example, my own work on Buang dialects again confirms the great importance speakers place in recognising the small linguistic details which differentiate one village from the next. In Mambump village (a central village of Buang 'A', referred to by Hooley (1970) as 'Wagau' dialect) where I lived, people distinguished not only among $A, B$ and $C$, but also among three sub-varieties of A, citing lexical and phonological correspondences, though knowledge of exactly what features differentiated $C$ from $B$ most were unable to say. The following quotation shows the close parallel with the Kewa and Narak cases cited above :

That people are interested in other languages and dialects is evident in linguistic play, particularly in mimicry, where it is possible to observe the stereotypes people hold about the phonology of other languages. Mambump people, mimicking ... Buang $B$ pretended to speak like toothless old people, making [s]'s into [š]'s ... (Sankoff 1968:104)

In addition to the detalled evidence from Kewa, Narak, and Buang, the very existence of small differences (e.g. In cognate percentages) reported from one village to the next, in situations where people were stated to be in close contact, in a number of studies (especially Dutton 1969, who has paid more attention to documenting such differences), bears witness to the fact that Papuans and New Guineans were often very much aware of the linguistic detalls, great or small, differentiating them from their neighbours.

Some readers may feel that this discussion of dialect difference has little to do with bilingualism, except in the case that the 'dialect' in question is really sufficiently distinct to be considered a separate language (and we have seen that there are many such marginal cases). However, from the point of view of a speaker who does not know of the existence of, or recognise any affiliation with, local groups speaking other 'dialects' of his own language, but who has through contact with near neighbours learned to recognise and understand (and perhaps also produce, sometimes only in a stereotyped form) their dialect or language, be the differences from his own great or small, perhaps the distinction 
is of secondary importance. This is not to say that people were unable to distinguish degrees of difference, as well as qualitative differences (as between language and dialect). The Buang device for measuring differences of degree was the length of time a person from one's home village would need to stay in village $X$ in order to be able to 'hear' (1.e. understand) the speech variety spoken there. This model was applied to speech varieties within their own language family. For unrelated languages, this model was not applied, they being regarded as qualitatively different.

Knowledge of foreign speech varieties, whether active or passive, varied enormously in precolonial New Guinea, but we do have evidence that where it did exist, it was socially valued. The next section attempts to set this differential knowledge and use within a social matrix.

\subsection{Multilingualism (Knowledge of Foreign Speech Varieties) and its Social Uses}

The reasons for the existence of multilingualism in precolonial Papua New Guinea have been cited as involving a combination of demographic considerations (especially population density and size of language groupings) and the socially necessary contacts of trade and intermarriage. It has been clear that even in isolates, in communities visited by foreign-language traders, and in border areas, knowledge (whether active or passive) of foreign speech varieties has not been uniformly distributed among all members of the population. Differential knowledge by sex has been discussed with respect to each of the three types of multilingual situation presented in 7.1.1.1. Here we shall briefly consider three other aspects of multilingualism: its prestige value, its role in oral literature and verbal art, and its possible relationship to language differentiation.

Salisbury's view that bilingualism 'is treated as a desirable accomplishment (Salisbury 1962:4) among the Siane has been mentioned in 7.1.1.1.3. above. Discussing the fact that men of high status often made speeches in Dene, he says (Salisbury 1962:8):

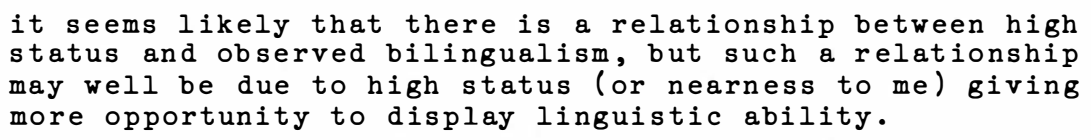

It is well known that traditional leaders in Papua New Guinea were highly skilled in rhetoric, and it may well be that in areas where the learning of forelgn languages was possible, aspiring politiclans added such foreign speech varieties to their battery of rhetorical skills. Biographical material on some present-day leaders tends to give supporting 
evidence. Handabe Tiabe (Member of the House of Assembly, Tari Open Electorate, 1964-67) would appear to fit into the category of a 'traditional leader' (Hughes and van der Veur 1965:408). When elected, he could not speak any of the three officlal languages of Papua New Guinea, but his multilingualism in Tari area languages was probably a mark of high status locally, and it may well have helped to increase his vote among linguistic groups other than his own. Another former Member of the House of Assembly noted for his linguistic skills was Stol Umut (Ra1 Coast Open Electorate). Harding (1965:199) notes that Umut's trilinguality in Komba, Selepet and Timbe was an important aspect of the ethnic base of his popularity. The multilingualism of these contemporary politicians in local languages offers some indication that the traditional leaders of the past may also have outstripped their fellows in such skills. The Gahuku leader Makis (Read 1965) would appear to be one example.

The use of foreign languages in oral literature and verbal art is also mentioned by Salisbury for the Siane, who generally sing songs in languages other than Siane. In Buang poetry, other-dialect synonyms are often used to make up semantic pairs necessary to the parallel structure of the poems. In Kewa, where the initiation cult proscribes the use of certain words, other-dialect equivalents are often used in their place (Franklin 1968:27-8; see also chapter 5.1.1. In this volume). Though in other regions verbal art and sacred language appear to differ from the everyday language more in terms of various systematic ways of altering everyday forms (cf. Laycock 1969 on Buin songs, as well as Malinowski's classic work on the language of Trobriand gardening magic, 1935), certainly for Kewa and Buang, knowledge of forelgn forms is part of the repertolre for verbal art and elaboration. In Buang, puns based on foreign synonyms constitute a commonly heard form of joke. This is one reason for the existence of the 'multiple cognates' discussed by Wurm and Laycock (1961:134) as being present
in a situation in which the speakers of one form of speech use only one of a pair of items with the same meaning, but recognize the other member of a pair when it is used by the speakers of another form of speech.

Based on Buang data, I would further specify 'use only one of a pair of items with the same meaning in their everyday speech, but use the other member of the pair in various marked usages, including poetry, irony, puns, etc.' This 'other member' may or may not be known to be the commonly used term for that meaning by neighbouring or distant groups.

As with the other two themes in this section, I begin with a suggestion from Salisbury, who seeks to relate the prestige of bilingualism 
to a more rapid rate of language differentiation. Quoting him at length, he states (Sallsbury 1962:11-12):
If to know a foreign language is prestigeful, and situations exist where interpretation is a ceremonial device for the individual to show his knowledge, while at the same time stressing the importance of the occasion, then interpretation will be used more than is necessary to ensure communication. It is clearly pointless to interpret speeches to people of the same speech community, but if differences of speech are magnified so that it is possible to deny that the neighbouring group speaks the same language, point is added to the making of interpretations. Innovations may be added to language with no fear of the language ceasing to be understandable, as one's own village are all aware of the innovation and can translate for strangers. In short, the counterpart of an emphasis on bilingualism and interpretation is an added in- tensity of local patriotism and ethnocentrism regarding the local dialect. Linguistic differentiation and change would then be given added impetus by political rivalries between groups, while existing speech barriers are encouraged by individuals wishing to prove their ability to learn difficult, exotic languages.

It seems possible and indeed quite apt to extend Salisbury's argument to the situation of local pride in difference, coupled with a rather thorough knowledge of the nature of the differences, even where such emphasis is not placed on translation. In fact this is a situation which appears to be extremely widespread in Papua New Guinea. Whether or not it really does cause more rapid differentiation of neighbouring speech varieties, or even more rapid overall change of all the speech varieties together is, however, not an easy question. It may be a situation in which lexical and phonological diffusion is favoured, coupled with many basic similarities in syntax and semantics which would allow for more communication with 'lower than usual' cognate percentages, as again has been observed all over Papua New Guinea. Areal features alding communication may indeed be diffused across language family boundaries, creating a Sprachbund-like situation.

Here we are venturing, but only very tentatively, into a consideration of the possible linguistic effects of a situation (language contact and bilingualism) which is itself only very imperfectly known. In order to go any further, a much better knowledge of the situation would be required. Nevertheless, it is clear that the way people use languages is of great importance in understanding the structure and relationships of those languages.

\subsubsection{SUMMARY}

The attempt in section 7.1.1. of this chapter to reconstruct the extent and nature of multilingualism in precolonial Papua New Guinea would appear to lead to a conclusion very different from the view 
expressed by Laycock on the subject, where he states that given the linguistic diversity of Papua New Guinea (Laycock 1966:44):

one would expect a fair amount of bilingualism, but in fact in pre-European times native knowledge of other languages was apparently not as extensive as was, for example, the knowledge of other languages on the part of Australian aboriginals. There are a number of reasons for this: (1) there was often extreme dissimilarity between neighbouring languages; (2) the major language groups in New Guinea are relatively large, larger than in Australia, so that it was possible to travel a fair distance without encountering very different tongues; (3) many factors operate against contact between different linguistic groups. In the Sepik area the main social unit was the village, and even trading with other villages of the same linguistic community was fraught with suspicion. Trading was carried on across linguistic groups - often in the form of 'silent trading', where, for example, hills natives would lay down their yams and sweet potato against the fish from the river, until an agreement was reached - but the more normal social interaction was warfare, where a knowledge of the other language was not necessary.

In my attempt to seek out cases of multilingualism and generalise from them, I did not mean to deny the existence, as well, of the type of situation Laycock describes. In sparsely populated areas, in areas where there were awesome natural barriers like swamps or high mountains, in areas where there were great cultural differences or a state of warfare which impeded amical communication, people would not speak or understand their neighbours' languages.

Indeed, cases of 'silent trade' are attested for areas other than the Sepik. Harding, describing trade encounters between the 'bush' and coastal peoples on the Ra1 Coast, says (Harding 1967:63-4):

At the old-time markets the two groups of men and women, one to three dozen people on each side, sat down in two rows facing each other. The bush people normally initiated the transaction by pushing forward a net bag of food and taking back the goods - fish, coconuts, and pots - which the Sio had in front of him... The exchanges were conducted largely in silence, without haggling or bargaining.

Hogbin makes a similar comment about trade between coastal and interior peoples on the southern side of the Huon Gulf (Hogbin 1947:247):

The peoples of the coast and the interior ... had no common tongue and had to conduct their barter either through a few interpreters or by means of signs.

Such cases seem to have occurred where a combination of geographical and cultural barriers made communication difficult, the prototypical case being where the people of the last mountain village in an inland trade clrcult came down to the coast to trade with the coastal dwellers. (Though in other areas, despite very great linguistic differences, e.g. in the case of Kolta-Motu, the mountain people came down to the coast and integrated with the coastal people.) 
For reasons explained in various parts of section 7.2.1. above, I do not feel that the first two of the reasons adduced by Laycock were in fact operative to any great degree. The third factor, as he himself admits, was variable, and depended very much on local circumstances. And Laycock himself does admit some bilingualism, as he goes on to say (Laycock 1966:44):

Nevertheless, many natives did pick up at least smatterings of languages, sometimes of several different languages, and there existed in native communities ... a small proportion of people with an interest in foreign cultures and languages. In complex linguistic areas like the sepik it was customary for young boys to be exchanged between villages at the age of about ten, so that they could grow up bilingual and mediate in disputes. But the knowledge of foreign languages was individual and restricted ....

In looking at the cases of multilingualism which have been described, and in attempting to draw inferences from them to those situations on which I have no information, I have come to a set of conclusions which must, however, differ from Laycock's. First, I believe that there has probably been in Papua New Guinea a great deal more multilingualism than is usually admitted. For various reasons, the subject has been very much neglected. Most of the ethnographic sources I consulted mentioned marriage and/or trade with neighbouring groups at least in a footnote, and these nelghbouring groups often turned out upon further checking to speak a different language, sometimes very different, but few ethnographers devoted any attention to the linguistic consequences. Conversely, many of the linguistic surveys explained the heightened proportion of cognates in certain unlikely speech varieties by postulating borrowing between the two, but did not state what type of bilingual situation might have produced the borrowing. There is a general lack of attention to boundary problems, a tacit acceptance of the 'one langue = one culture' assumption, and a concentration on phenomena internal to the language or culture in question, with a consequent neglect, even underrating, of boundary problems of all sorts. This focus is maintained despite the considerable evidence that linguistic identity was generally highly local, as one further quotation, this time for Kewa, indicates:

Socially, the Kewa language does not represent any political or national group. In fact, many speakers from separate dialects will deny that they speak the same language. (Franklin 1968:1)

Glasse is the only author to state otherwise, remarking that (Glasse 1968:20):

Unlike many highland peoples, the Huli are conscious of their cultural homogeneity and they are aware of the differences between their own social institutions and those of their 
neighbours. This cultural self-consciousness may be partly attributed to the mobility of the population. With no high mountain ranges to cross, travel is comparatively easy, and people often maintain two or three homesteads in different places.

At least on one of their borders, however, the Hull are not at all clearly demarcated from their (linguistically) most different neighbours, the Duna, and there is a sizeable area of bilingualism, as described in 7.1.1.1.4. above.

Second, over much of Papua New Guinea, though people had a great deal of pride in, and derived some of their identity from their own local speech varlety, often exaggerating its differences from the speech of their neighbours, this went hand in hand with an openness of attitude and an interest in the learning of other speech varieties.

Third, language boundaries were not necessarily considered barriers to trade, intermarriage, and other types of communication.

Fourth, inasmuch as the learning of other speech varieties, in border areas, coastal areas visited by traders, and language isolates, was conditioned by social roles and relationships, multilingualism was differentially distributed among members of any given population.

Fifth, where multilingualism did exist, it was a resource which formed part of. the set of rhetorical devices put to use by politicians and other orators.

The above account is necessarlly lacking in some details, given the paucity of information avaliable on multilingualism in precolonial Papua New Guinea. Many readers with personal experience of one or another of the types of situations described may find some of the details to be in error, and perhaps this will urge them to make available more information. The wealth of material published since approximately 1965 , particularly the many language surveys of a large number of districts, has made possible this attempt at reconstruction, and it is hoped that, by the end of another decade, the picture may be more complete.

Clearly, the hundred years or so of colonial rule in Papua New Guinea has wrought enormous changes of many kinds, not least in the area of multilingualism. In section 7.1.2., we turn to a consideration of multilingualism directly related to the presence of Europeans in Papua New Guinea.

\subsubsection{MULTILINGUALISM IN THE COLONIAL PERIOD}

With the post-independence period of Papua New Guinea history Just beginning, the time is opportune for an assessment of the multilingual situation at the end of approximately 100 years of colonial rule. 
Section 7.1.2.1. below will be devoted to a brief examination of the spread of regional lingue franche, mainly by the various Christian missions, and in section 7.1.2.2., we shall consider the use of the three official languages of Papua New Guinea: Hiri Motu, Tok Pisin and English.

\subsubsection{REgIONAL LANGUAGES IN PAPUA NEW GUINEA}

In some cases, missionary groups in Papua New Guinea spread the use of a language which was already widely spoken as a second language. Thus the Methodists in the Milne Bay area used Dobu, an Austronesian language widely known by participants in the Kula trade, as we saw in 7.1.1.1.2. Similarly, the London Missionary Society used Motu in the Central District of Papua.

An Austronesian language which has become a regional lingua franca is Tolai, as Wurm (1971b:1018) explains as follows:

The numerically large (close to 30,000 speakers) Austronesian Tolai of northern New Britain has been adopted as the mission language by the Methodist Mission throughout the New BritainNew Ireland region, and it is also used by the Catholic Mission, but only for the Tolai area itself. The language is now a quite widespread lingua franca in these areas.

The figure of 63,000 cited as the number of Tolai-speakers by Beaumont (1972:13) may well include the total of first and second-language speakers.

Two other Austronesian languages widely used by the Lutheran mission are Graged in the Madang District and Yabêm in the Huon Gulf area of the Morobe District. Yabêm, which according to Hooley and McElhanon (1970:1086) has 2,900 first-language speakers, probably numbers at least 15,000 second-language speakers, 9 and is used to some extent at least as a regional lingua franca in non-mission contexts. (This generalisation is based on my own observations of situations in which Buangspeakers communicated with other Morobe District Lutherans in Yabêm, despite the fact that both parties to the interaction could have used Tok Pisin. Such languages may be of preferred usage in some cases in order to stress regional or religious solidarity.)

Wedau is another Austronesian language which, according to Wurm (1966:141), has been used as a lingua franca by the Anglican Mission in the Milne Bay District.

A number of Papuan languages have also been spread as lingue franche by various missions. These include Orokolo in the Gulf District (Wurm 1971b:1018) as well as Toaripi, also in the Gulf District, by the London Missionary Society and the Roman Catholics, and Kiwai, in the Fly Delta area of the Western District, by the London Missionary Socieiy (Wurm 1966:141). 
Lastly, Wurm has this to say about Kâte, spoken as a first language by approximately 4,000 people in the sub-coastal mountains near the tip of the Huon Peninsula:

A striking example of the development of a missionary lingua franca is provided by Kâte, a Papuan language in the Huon Peninsula area of the New Guinea mainland. This language, which was originally spoken by only a few hundred natives, was adopted by the Lutheran Mission as one of their mission

languages towards the end of the last century, and is now believed to be spoken and understood by around 60,000 natives throughout a large portion of north-east New Guinea, including parts of the Highlands Districts. (Wurm 1971b:1018)

It may be that the heyday of regional lingue franche has passed. At one time, many people wishing to send their children to school had no cholce but to have them educated (at least at the primary level, which is as far as most children were sent) in one of these lingue franche. But 'since 1960 it has been government policy not to register or recognise mission schools which use such languages' (Rowley 1965:146), which means lack of subsidy for these schools. With no institutional support, regional lingue franche may lose ground to Tok Pisin, English, or Hiri Motu, though to the extent to which they continue to be used as religious languages, they may continue to be spoken as second languages by many people for some time to come. Though the regional lingue franche propagated by the various missions number many thousands of speakers, none of them surpasses the largest of the Papuan languages discussed in section 7.1.1., and in terms of their numbers of speakers, they are no match for the national lingue franche to be discussed below in 7.1.2.2.

\subsubsection{OFFICIAL LANGUAGES IN PAPUA NEW GUINEA}

\subsection{Hiri Motu}

of the lingue franche discussed earlier in this chapter, only one has acceded to the status of one of Papua New Guinea's official languages. This is the language today called Hirl Motu, and known in much of the linguistic literature, as well as in official census documents (at least of the colonial period), as 'Police Motu'. After a spectacular start as one of the most widely used precolonial trade languages, this lingua franca was later adopted by the administration of British New Guinea for use by the native police force, the Royal Papuan Constabulary - hence its name 'Police Motu' - and as the unofficial administrative language for native affairs. (Wurm 1969:35)

Hirl Motu is an official language in that it is one of the three languages in which members may speak in the House of Assembly, and in which simultaneous translation is provided. Official government documents, notices, etc., are printed in three languages, and the radio 
stations daily broadcast the news in all three. But very rarely is a speech in Hiri Motu actually heard in the House of Assembly. Of the three official languages, it is Hiri Motu that has the fewest speakers overall, and that is the most restricted regionally.

Table 2 shows the overall proportion of speakers of Hiri Motu and of the other two official languages, Tok Pisin and English. Figures are from the 1966 population census of Papua New Guinea, and the estimates are probably all somewhat exaggerated, since language knowledge was based at least to some extent on self-reporting, although census takers attempted to check this where possible.

TABLE 2

Population of Ten Years and Over Speaking Each of the Official Languages of Papua New Guinea in 1966. (Population Census: Data Abstracted From Table 14, Preliminary Bulletin 20.)

\begin{tabular}{|l|r|r|r|c|}
\hline Language & Male & Female & Total & $\begin{array}{l}\text { Proportion of } \\
\text { total population } \\
\text { 10 years and older }\end{array}$ \\
\hline English & 130,429 & 62,908 & 193,337 & $13.3 \%$ \\
Tok Pisin & 369,855 & 161,835 & 531,690 & $36.5 \%$ \\
Hiri Motu & 86,665 & 31,910 & 118,575 & $8.3 \%$ \\
\hline
\end{tabular}

In comparing the figures given for the three official languages with those cited for the large languages of the Highlands, it should be remembered that population estimates for the latter included all speakers, whereas these are based on speakers over age ten only.

The regional character of Hirl Motu becomes more evident on examining Table 3, which shows the number and proportion of speakers of the three languages by District. 10 It is readily observable that second-language speakers of Hiri Motu are almost entirely confined to the five Districts of coastal Papua, and that, in all five, Hirl Motu speakers greatly outnumber Tok Pisin speakers. In addition, a closer look at the census figures showing how many people speak various combinations of the three official languages shows that in all of these Districts, many thousands more speak 'only Hirl Motu' than 'only English' (approximately 53,300 versus 24,900). Thus for the five Papuan coastal Districts, Hiri Motu serves as by far the most practical lingua franca. 
TABLE 3

The Number and Proportion of Papuans and New Guineans Age Ten and Over Speaking Tok Pisin, English and Hiri Motu in Each District

\begin{tabular}{|c|c|c|c|c|c|c|c|}
\hline & \multirow[b]{2}{*}{ Districts } & \multicolumn{2}{|c|}{ Tok Pisin } & \multicolumn{2}{|c|}{ English } & \multicolumn{2}{|c|}{ Hiri Motu } \\
\hline & & No. & 8 & No. & 8 & No. & 8 \\
\hline \multirow{5}{*}{$\begin{array}{l}\text { Papuan } \\
\text { Coastal }\end{array}$} & Central & 25,630 & 28.2 & 37,381 & 41.1 & 55,018 & 60.5 \\
\hline & Northern & 7,267 & 19.1 & 13,464 & 35.4 & 14,686 & $\underline{38.6}$ \\
\hline & Gulf & 2,873 & 8.0 & 7,189 & 20.1 & 12,097 & 33.8 \\
\hline & Milne Bay & 3,547 & 5.2 & 16,169 & 23.9 & 16,714 & 24.7 \\
\hline & Western & 1,844 & 4.5 & 5,305 & 12.8 & 9,825 & 23.8 \\
\hline \multirow{5}{*}{$\begin{array}{l}\text { New Guinea } \\
\text { Islands }\end{array}$} & New Ireland & 32,550 & 94.2 & 8,687 & 25.1 & 253 & 0.7 \\
\hline & Manus & 11,784 & 89.2 & 4,639 & $\underline{35.3}$ & 211 & 1.6 \\
\hline & West New Britain & 21,026 & $\underline{75.7}$ & 5,577 & 20.1 & 207 & 0.7 \\
\hline & East New Britain & 48,464 & 69.5 & 20,299 & 29.1 & 1,356 & 1.9 \\
\hline & Bougainville & 31,843 & 68.0 & 11,036 & 23.6 & 253 & 0.5 \\
\hline \multirow{4}{*}{$\begin{array}{l}\text { New Guinea } \\
\text { Coastal }\end{array}$} & East Sepik & 79,680 & $\underline{76.6}$ & 11,962 & 11.5 & 756 & 0.7 \\
\hline & West Sepik & 45,208 & 67.4 & 4,314 & 6.4 & 318 & 0.4 \\
\hline & Madang & 62,426 & 61.5 & 11,293 & 11.1 & 957 & 0.9 \\
\hline & Morobe & 65,634 & 47.1 & 14,942 & 10.7 & 2,582 & 1.9 \\
\hline \multirow{4}{*}{ Highlands } & Eastern Highlands & 35,237 & 26.3 & 7,296 & 5.4 & 1,252 & 0.9 \\
\hline & Chimbu & 20,706 & 17.4 & 3,519 & 2.9 & 339 & 0.3 \\
\hline & Western Highlands & 26,385 & 13.0 & 6,922 & 3.4 & 687 & 0.3 \\
\hline & Southern Highlands & 9,592 & $7 \cdot 7$ & 3,346 & 2.7 & 1,065 & 0.9 \\
\hline
\end{tabular}

NOTE : For each language, underlined percentages are those which exceed the national average for that language. (Data abstracted from Table 11 of the 1966 Preliminary Census Bulletins for each district.) Note that the (now abolished) political division between Papua and New Guinea is entirely unrelated to the distinction between Papuan and Austronesian languages. 


\subsection{Tok Pisin}

Useful materials on the linguistic aspects of Tok Pisin (otherwise known as New Guinea Pidgin, Pidgin (in the census reports), Melanesian Pidgin, and Neo-Melanesian) exist in abundance, e.g. In addition to the chapters in this volume, Dutton 1973; Hall 1943; Laycock 1970a;

Mühlhäusler 1976; Sankoff and Laberge 1973; Sankoff 1977; Wurm 1971c. There is also considerable literature available on the history and use of Tok Pisin, three of the most informative treatments being Laycock 1970b, Salisbury 1967, and Wurm 1966-67, though Mühlhäusler's contributions to the present volume (see 7.4.1.1., 7.4.1.4.2.-3.) and his contributions to Wurm, ed. with others 1978 are the most comprehensive summaries to date.

We can see from Tables 2 and 3 in 7.1.2.2.1. that Tok Pisin is currently the most important language in Papua New Guinea as far as bilingualism is concerned. Not only does it have numerically more than twice as many speakers as either of the other two official languages; it also has a very impressive regional spread. As indicated in Table 3 in 7.1.2.2.1., Tok Pisin is the most widely spoken officlal language in all but the five Papuan Coastal Districts, 1.e. Central, Northern, Gulf, Milne Bay, and Western.ll In all of the New Guinea Coastal and Islands Districts, Tok Pisin is spoken by a proportion of people considerably higher than the national average of $36.5 \%$. And even in the New Guinea Islands Districts, where the proportion of English-speakers is far ahead of the national average of $13.3 \%$, the number of Tok Pisinspeakers is in every case more than double the number of Englishspeakers, and there are very few 'English only' speakers. Tok Pisin currently dominates as the language of widest currency in the largest proportion of districts.

\subsection{English}

As we might expect, English is dominant as an official language in none of the districts of Papua New Guinea. In the Papuan Coastal Districts it runs second, often a close second, to Hiri Motu; in all the other districts it runs a rather poor second to Tok Pisin. Also quite expectedly, the districts where English-speakers exceed the national average are those which have been the longest colonised and where the early missionaries set up schools, 1.e. the New Guinea Islands and all of the Papuan Coastal Districts except in Western District. English-speakers tend to be young, as English schools in any numbers are largely a phenomenon of the 1960s and 1970s. Many of them are 
still in school, and their numbers have been swelled in the 1971 census when the six to ten year olds in 1966 entered the population and were asked about their knowledge of the official languages.

\subsubsection{QUALITATIVE ASPECTS OF MULTILINGUALISM IN PAPUA NEW GUINEA'S OFFICIAL LANGUAGES}

From many points of view, Hiri Motu, Tok Pisin and English occupy very different roles from those served by the large languages of the Highlands and even the regional lingue franche. Most importantly, they are essentially second languages, learned by the people of Papua New Guinea in addition to their native languages, and having very few if any native speakers. In theory at least, none of these is identified as the 'Tok Ples' (native language) of a particular, geographically located group. Hiri Motu, however, is very closely identified with Motu, with Port Moresby, and with Papua generally. In the minds of the majority of non-Hiri Motu speakers, 'Hiri Motu' and 'Motu' are indistinguishable, being the Tok Ples of the Motu people of the Port Moresby area. This close regional identification detracts somewhat from one of the usual advantages of a lingua franca which is no-one's native language - its neutrality.

For most New Guineans, Tok Pisin is such a neutral language. Being, in the view of most New Guineans, no-one's Tok Ples, it is thereby in the public domain and can be learned with impunity. That is, learning it will not succeed in improving the fortunes of some other (its native) group. On the other hand to many Papuans, this is exactly the connotation of Tok Pisin, which, as the lingua franca of New Guinea, is viewed as a threat to the use and status of Hiri Motu. Despite the antagonism of Papuan nationalists, however, Tok Pisin appears to be making definite inroads. Though many of the 25,630 Tok Pisin speakers in the Central District are New Guinean migrants resident in the Port Moresby area, an increasing number of Papuans are also learning Tok Pisin. On a visit to Port Moresby in 1973, I was surprised to note the increase in the use of Tok Pisin by Papuans conversing with New Guineans, a situation which had changed considerably since my last visit in 1971.

With the continuing spread of Tok Pisin, in confunction with very rapid urban growth, various urban communities in New Guinea now have small but growing communities of people for whom Tok Pisin has become a Tok Ples, 1.e. who speak it as a native language. These are mainly young people, children whose parents regularly communicate with each other in Tok Pisin, often because they have no other language in common. Though many of these children are learning English at school, any type 
of 'continuum' situation between Tok Pisin and English is still virtually non-existent. The variety of Tok Pisin most heavily larded with English loans is that spoken by national politicians, who have incorporated a great deal of English parliamentary vocabulary into their discussions of parliamentary affairs. Outside of this very restricted group, one hears virtually no speech which is in any way 'in between' Tok Pisin and English. The two languages as spoken at present are too far apart in structure for any mutual intelligibility beyond the understanding of the occasional vocabulary item, as I discovered in testing fluent Tok Pisin speakers whose native language is Buang for their comprehension of simple stories in English (Sankoff 1968, chapters 9 and 10). Most New Guineans who speak both English and Tok Pisin use very little English outside of contexts where it is obligatory such as school or work.

Of the three official languages, it is clearly English which is regarded as the most neutral, $1 . e$. the least related to any particular group. There are probably no more than a few thous and Papuans and New Guineans at most who speak it as a native language. But in many ways it is regarded as almost too neutral, too foreign. There is no doubt that knowledge of English is a very great advantage, economically and politically, a fact which is not lost on the many thousands of parents whose central goal for their children is to learn English well (cf. Sankoff 1976). Nevertheless except among some very restricted groups, such as tertiary-level students, very little English is used outside of formal contexts.

A second commonality among the three official languages is that all of them are spoken by very many more men than women. $67 \%$ of Englishspeakers are male, as compared with $70 \%$ of Tok Pisin-speakers and $73 \%$ of Hiri Motu-speakers. 12

Thirdly, the proportion of urban speakers of all of these languages is much higher than in rural areas. Already in Table 3 given in 7.1.2.2.1., we saw that the only non-Papuan districts in which the number of Hiri Motu-speakers rises above 1,000 are Eastern Highlands, Morobe, and East New Britain, due to the presence of Goroka, Lae and Rabaul respectively. The location of Port Moresby in the Central District is responsible for the relatively high proportion of Tok Pisinspeakers there. Table 4 shows the proportion of speakers of each of the three official languages in the seven major towns of Papua New Guinea. In each case, the proportion of speakers of each of the three languages is higher than that for the district in which the town is located as a whole. This is due to the presence in towns of many Papuans 
and New Guineans from other areas and districts, to the presence of most of the educated and highly skilled members of the labour force, and to the greater number of schools located in urban areas. The very substantial increase in the urban population indicated in Table 4 for the period between 1966 and 1971 will no doubt have wide ramifications for multilingualism in Papua New Guinea in the 1970s.

\section{TABLE 4}

Percentages of Speakers of Each of the Three Official Languages of Papua New Guinea in the Seven Major Towns

\begin{tabular}{|c|c|c|c|c|c|}
\hline Major towns & $\begin{array}{l}\text { \& for } \\
\text { Tok Pisin }\end{array}$ & $\begin{array}{l}8 \text { for } \\
\text { English }\end{array}$ & $\begin{array}{l}8 \text { for } \\
\text { Hiri Motu }\end{array}$ & $\begin{array}{c}\text { Population } \\
1966\end{array}$ & $\begin{array}{l}\text { Population } \\
1971\end{array}$ \\
\hline Port Moresby (Central) & 54.9 & 64.4 & 77.8 & 31,983 & 50,988 \\
\hline Lae (Morobe) & 94.2 & 36.1 & 14.8 & 13,341 & 28,494 \\
\hline Rabaul (E. New Britain) & 97.1 & 37.4 & 11.9 & 6,925 & 20,700 \\
\hline Madang (Madang) & 96.2 & 30.8 & 8.0 & 7,398 & 13,472 \\
\hline Wewak (E. Sepik) & 96.2 & 27.8 & 5.2 & 7,967 & 11,383 \\
\hline Goroka (E. Highlands) & 89.6 & 31.6 & 14.3 & 3,890 & 9,238 \\
\hline Mount Hagen (W. Highlands) & 82.7 & 27.0 & 13.5 & 2,764 & 8,398 \\
\hline TOTAL & & & & 74,268 & 141,973 \\
\hline
\end{tabular}

NOTE: (Expatriates are excluded as in all the tables.) Language figures are taken Irom the 1966 Population Census; population figures from 1971 Population Census (Preliminary Bulletin 1) are provided for camparison, 1971 language figures being not available at the time of writing.

\subsubsection{REGIONAL DIFFERENCES IN MULTILINGUALISM}

We are now in a position to characterise each of the four regions into which the districts were grouped in Table 3 with respect to the prevalence and nature of multilingualism. In 7.1.2.2. above, the New Guinea Is lands and the Papuan Coastal Districts were characterised as 'most multilingual', as in all of them except the Western District of Papua, the proportion of English-speakers was higher than the national average and, in addition, each of them was also higher than the national average for one of the other two languages, Hirl Motu for the Papuan Coastal Districts, and Tok Pisin for the New Guinea Islands Districts. But an examination of Table 5 shows that a far greater proportion of the population of the New Guinea Islands Districts is bilingual or multilingual in one or more of the official languages. In fact, the proportion of people who speak none of these three languages ranges from only 5.2\% in New Ireland to $31.0 \%$ in Bougainville. In the Papuan Coastal 
Districts, by contrast, the proportion speaking none of the three officlal languages ranges from $23.6 \%$ in the Central District to $70.5 \%$ in the Western District. As the national average proportion of people who speak none of the three official languages is $55.3 \%$, we see that Milne Bay as well as the Western District exceeds this proportion. Though many people in these districts may be multilingual in local or regional languages, their multilingualism does not extend to the official languages of Papua New Guinea, as well over half of them speak none of the three.

From this perspective, the New Guinea Coastal Districts appear to be characterised by much more multilingualism than the Papuan Coastal Districts. Though only one language dominates (Tok Pisin), the fact that large numbers of people speak it means that relatively few are unable to speak at least one of the three official languages. This figure ranges from 22.9\% in the East Sepik District to $51.4 \%$ in the Morobe District, a proportion which is below the national average in every case.

TABLE 5

The Number and Proportion of Papuans and New Guineans Age Ten and Over Who Speak Neither Tok Pisin Nor Hiri Motu Nor English, by District. (Data Abstracted from Table 13 of the 1966 Preliminary Census Bulletins for Each District.)

\begin{tabular}{|c|c|c|c|c|c|}
\hline \multicolumn{3}{|c|}{ New Guinea Islands } & \multicolumn{3}{|c|}{ Papuan Coastal } \\
\hline New Ireland & 1,809 & $5.2 \%$ & Central & 21,137 & $23.6 \%$ \\
\hline Manus & 1,128 & $8.6 \%$ & Northern & 14,515 & $38.2 \%$ \\
\hline West New Britain & 6,578 & $23.7 \%$ & Gulf & 19,381 & $54.2 \%$ \\
\hline East New Britain & 16,143 & $23.2 \%$ & Milne Bay & 41,575 & $61.3 \%$ \\
\hline Bougainville & 14,515 & $31.0 \%$ & Western & 29,141 & $70.5 \%$ \\
\hline \multicolumn{3}{|c|}{ New Guinea Coastal } & \multicolumn{3}{|c|}{ Highlands } \\
\hline East Sepik & 23,837 & $22.9 \%$ & Eastern Highlands & 97,631 & $72.8 \%$ \\
\hline West Sepik & 21,621 & $32.3 \%$ & Chimbu & 98,216 & $82.4 \%$ \\
\hline Madang & 38,586 & $38.1 \%$ & Western Highlands & 174,337 & $86.2 \%$ \\
\hline Morobe & 71,698 & $51.4 \%$ & Southern Highlands & 113,895 & $91.3 \%$ \\
\hline
\end{tabular}

Lastly, it is clear that in the densely populated districts of the Central Highlands of Papua New Guinea, a very small proportion of people speak any of the three official languages. In all cases, the proportion of people who speak none of these languages is much higher than the national average, and is everywhere over 70\%. These are the people who, along with a majority of the inhabitants of the Gulf, Milne Bay and Western Districts, are the most cut of from communication on the 
national level. It must be remembered that it is in the Highlands that the majority of the very large language groups are located, and thus the speakers of these large languages are at least 1deally part of communication networks which include tens of thousands of people. But the fact that the great majority of them do not know any of the three official languages probably implies little travel or contact with people outside of their own small local groups, not to mention their corresponding lack of access to national-level news through the main medium of mass communication, the radio.

\subsubsection{SUMMARY}

Nowhere in section 7.1.1. did we attempt to estimate the number or proportion of people with some degree of competence in languages other than their own, except on a very local basis. It is even harder to combine the qualitative picture obtained from looking at types of multilingual situations with respect to local languages, with the quantitat1ve data on knowledge of the official languages.

We know that a majority of the Papua New Guinean population does not speak any of the official languages, 1.e. 55.3\%. Only 1.9\% claim to speak all three, and these would virtually all be people who also speak their own language, from which we can draw the conclusion that this tiny minority is quadrilingual at least. Similarly for the $6.9 \%$ claiming to speak both English and Tok Pisin, and the $1.8 \%$ claiming English and Hiri Motu - most of these people would be at least trilingual. As for those who speak, of the three official languages, only English (2.7\%), only Tok Pisin (30.0\%), or only Hirl Motu (3.7\%), most of them would be at least bilingual in one of the three and their own language.

In examining the two big subdivisions of the population, 1.e. the $45 \%$ who speak at least one of the official languages and the $55 \%$ who do not, an educated guess is as far as we can go in estimating the multilingualism of these two groups in terms of local languages or regional lingue franche. It is very likely that there is a great deal more multilingualism in local and regional languages among the 45\% than among the 55\%, as these people tend to belong to smaller language groups (with consequently greater border area and thus more opportunity to learn nelghbouring languages) and to live in areas nearer the coast where there was greater chance of learning a trade language in the precolonial era, and greater chance of learning one of the mission-propagated lingue franche over the last several generations. 


\section{G. SANKOFF}

$N O T E S$

1. I wish to express my thanks to the Buang people of Mambump Village, who initiated me into the subtleties of multilingualism in New Guinea. I also wish to thank Plerrette Thibault and Marjorie Topham for their help in preparing the manuscript.

2. I will use the terms 'multilingual' and 'multilingualism' in the generic sense throughout, $1 . e$. to refer to speakers having competence in more than one language. 'Bilingual', 'trilingual' etc., will be used to refer more specifically to particular groups or individuals having competence in two, three, etc., languages.

3. The 25 other Austronesian languages of New Britain discussed in Chowning 1970 have not been included because she does not cite population figures.

4. It also may reflect the fact that since the majority of linguists are men and therefore also speak mainly with men in the language groups they visit (often for reasons of social acceptability, as noted by Laycock (1965:13)), they have incomplete information on the language competence of women.

5. Barton (1910:119-20) gives a wordlist of over 100 words in what he calls the 'lakatol language' used as a trading language between the Elema and the visiting Motu traders. Checking this list against the dictionary in Wurm and Harris' Police Motu manual (1963), I found that of the 105 lexical 1tems I could locate in both lists, only 21 were obviously the same words. Whether this means that Barton's list is aberrant or that Hiri Motu has changed very drastically in the intervening 50 years, is impossible for me to judge. 
6. The only exception to this in the four examples discussed appears to be the Kolta, bilingual in Motu. As very close neighbours of the Motu-speakers, however, they had relations other than trade with the Motuans, specifically a great deal of intermarriage.

7. Hooley (1970, 1971) gives slightly higher cognate percentages among these three, but the relationships remain the same. 'A' is referred to as Mambump or Wagau Buang, ' $B$ ' as Mapos Buang, and ' $C$ ' as Manga.

8. In the sixth, Koita, the complexity of the linguistic situation is due to a great deal of bilingualism in Motu, as discussed in 7.1.1.1.2., rather than to dialect diversity.

9. This is a conservative estimate generalised from my own observations on the use of Yabêm at a Lutheran mission conference (known as the Sam) held by the Blangkoun Congregation in headwaters Buang in 1966 . It is interesting to note that the close similarities between Yabêm and Bukaua (Capell 1949) sald by Hogbin to have served as a lingua franca in the Huon Gulf area, may have alded in the dissemination of Yabêm.

10. This paper, written in 1974, conserves the then current political subdivisions of Papua New Guinea, 1.e. the Districts whose titles appear in Table 3 and elsewhere, principally because these are the categories of the 1966 and 1971 census data upon which this section is largely based. The current Provinces retain the old District boundaries.

11. Landtman (1927) discusses the 'pidgin-English' spoken by the Kiwai of the Fly River Delta during the period 1910-12, claiming that 'many men in the coast villages' knew it.

The explanation is that the men were commonly recruited to
work on the pearl-fishing boats in Torres Straits and on the
plantations in Central and Eastern Divisions, and their own
languages and dialects being so different that they could not
understand each other, pidgin-English became a sort of lingua-
franca among themselves which they learnt from each other and
spoke fairly well on returning to their villages after a
period of three to six months of work. (Landtman $1927: v$ ) Though this variety is probably more akin to that spoken in the Torres Straits (cf. Dutton 1970b), I do not know how many Kiwal still speak 1t, and whether they consider it to qualify as Tok Pisin and would report themselves as speakers of 1 it in the census. I am indebted to Ann Chowning for bringing Landtman's discussion to my attention. 
12. This skewing in favour of males strongly reflects the colonial history of Papua New Guinea, as it has always been men who were the more involved in the European spheres of work and, later, schools. It was, of course, the plantation system which fostered the spread of Tok Pisin. Writing in 1943, Reed made a 'conservative estimate' of the number of Tok Pisin-speakers as approximately 100,000, or about one-fifth of the total population of the Mandated Territory as of the 1936 census. This estimate is based, he says:

first, on the assumption that all indentured natives learn to speak pidgin; second, on the native labor statistics since the inauguration of civil government by the Australians in 1921. The total number of contracts made between 1921 and 1936 has been 425,000, with five years as the average period of contract. Thus some 85,000 work boys have learned pidgin under the Australian regime alone. The number of natives who learned the speech during German times, together with the wives and children of work boys who have acquired the language and pupils of the mission schools, would certainly account for another 15,000. (Reed 1943:284, n.39) 


\subsubsection{MULTILINGUALISM IN PAPUA NEW GUINEA}

\section{BIBLIOGRAPHY}

BARTON, F.R.

1910 'The Annual Trading Expedition to the Papuan Gulf'. Chapter $8(96-120)$ of Seligman 1910.

BEAUMONT, C.H.

1972 'New Ireland Languages: A Review'. PL, A-35:1-41.

BEE, Darlene

1965 'Usarufa Distinctive Features and Phonemes'. PL, A-6: $39-68$.

BERNDT, Catherine $\mathrm{H}$.

1954 'Translation Problems in Three New Guinea Highland Languages'. Oceania 24:289-317.

BERNDT, R.M.

1962 Excess and Restraint. University of Chicago Press.

BETTISON, D.G., HUGHES, C.A. and P.W. van der VEUR, eds

1965 The Papua-New Guinea Elections 1964. Canberra: The Australian National University.

BROOKFIELD, H.C. and Paula BROWN

1963 Struggle for Land. Melbourne: Oxford University Press.

CAPELL, A.

1949 'Two Tonal Languages of New Guinea'. BSOAS 13:184-99.

1969 A Survey of New Guinea Languages. Sydney University Press. 
1971 'The Austronesian Languages of Australian New Guinea'. In: Sebeok, ed. 1971:240-340.

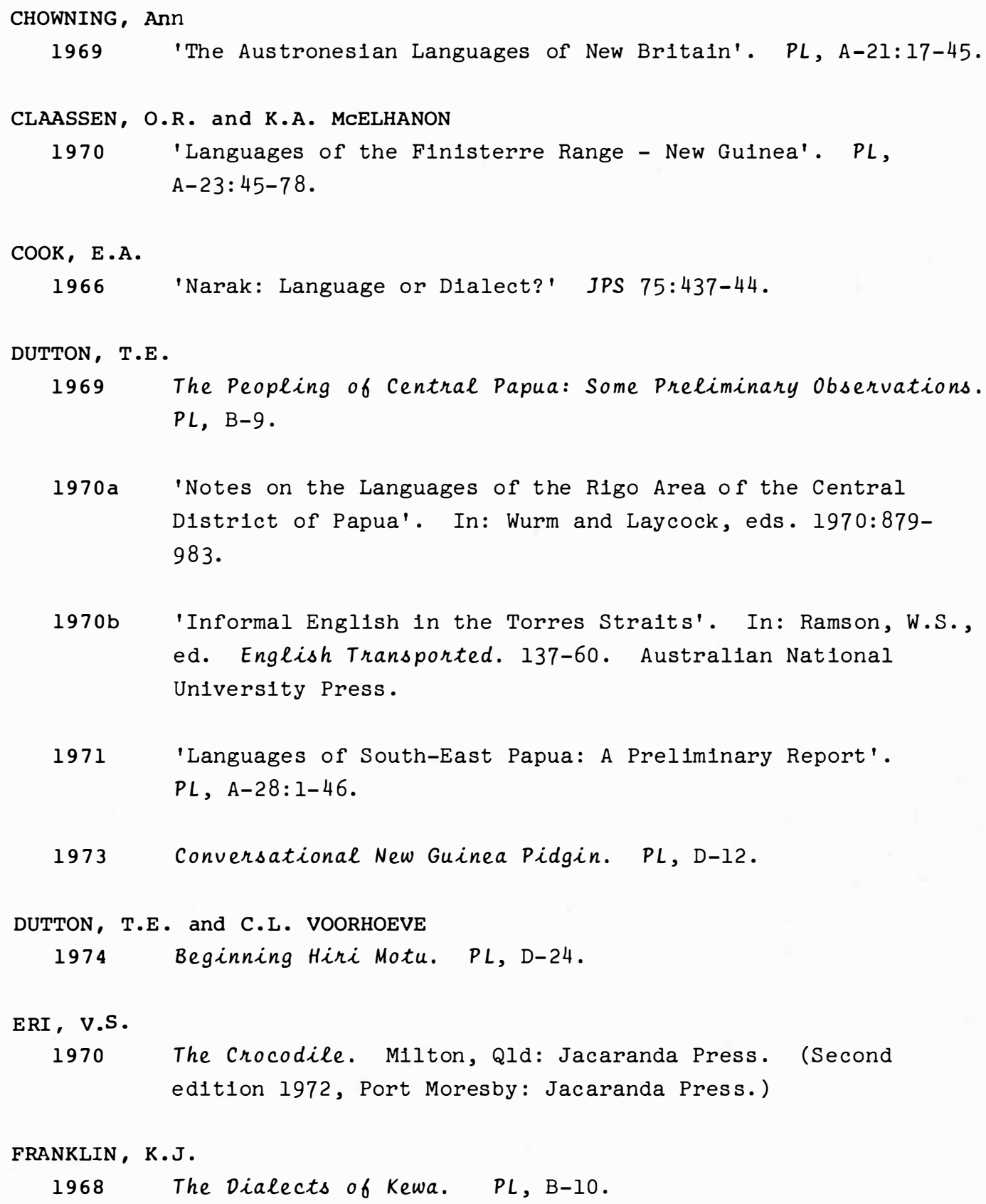


GLASSE, R.M.

1968 Huli of Papua: A Cognatic Descent System. Cahiers de l'Homme: Ethnologie - Gkographie - Linguistique. Nouvelle série VIII. Paris: Mouton, and École Pratique des Hautes Études.

HALL, R.A., Jr

1943 Melanesian Pidgin English: Grammar, Texts, Vocabulary. Baltimore: Linguistic Society of America.

HARDING, T.G.

1965 'The Ral Coast Open Electorate'. In: Bettison, Hughes and van der Veur, eds. 1965:194-211.

1967 Voyagens of the Vitiaz Strait: A Study of a New Guinea Trade System. Seattle: University of Washington Press.

HEALEY, A.

1964 The Ok Language Family in New Guinea. Ph.D. thesis, Australian National University, Canberra.

HOGBIN, H.I.

1947 'Native Trade Around the Huon Gulf, North-Eastern New Guinea'. JPS 56:242-55.

HOOLEY, B.A.

1970 Mapos Buang - Territory of New Guinea. Ph.D. dissertation, University of Pennsylvania.

1971 'Austronesian Languages of the Morobe District, Papua New Guinea'. OL 10:79-151.

HOOLEY, B.A. and K.A. MCELHANON

1970 'Languages of the Morobe District - New Guinea'. In: Wurm and Laycock, eds. 1970:1065-94.

HUGHES, C.A. and P.W. van der VEUR

1965 'The Elections: An Overview'. In: Bettison, Hughes and van der Veur, eds. 1965:388-429. 
LANDTMAN, G.

1927 The Kiwai Papuans of British New Guinea. London:

Macmillan.

LAYCOCK, D.C.

1965 The Ndu Language Family (Sepik District, New Guinea). $P L, C-1$.

1966 'Papuans and Pidgin: Aspects of Bilingualism in New Guinea'. Te Reo 9:44-51.

1969 'Sublanguages in Buin: Play, Poetry, and Preservation'. $P L, A-22: 1-23$.

1970a Materials in New Guinea Pidgin (Coastal and Lowlands). $P L, D-5$.

1970b 'Pidgin English in New Guinea'. In: Ramson, W.S., ed. English Transportedi Essays on Australasian English. 102-22. Canberra: Australian National University Press.

1973 'Sissano, Warapu, and Melanesian Pidginization'. Papers

(1976) of the First International conference on Comparative Austronesian Linguistics, 1974 - Oceanic. OL 12:245-78.

MALINOWSKI, B.

1935 Coral Gardens and Their Magic. vol.2. London: Allen and Unwin.

1966 Argonauts of the Western Pacific. Seventh Impression. (First published 1922). London: Routledge and Kegan Paul.

McKAUGHAN, H., ed.

1973 The Languages of the Eastern Family of the East New Guinea Highland Stock. Seattle and London: University of Washington Press.

MÜHLHÄUSLER, P.

1976 Growth and Structure of the Lexicon of New Guinea Pidgin. $\mathrm{Ph}$.D. thesis, Australian National University, Canberra. To be published, in a revised form, as $P L, C-52$. 


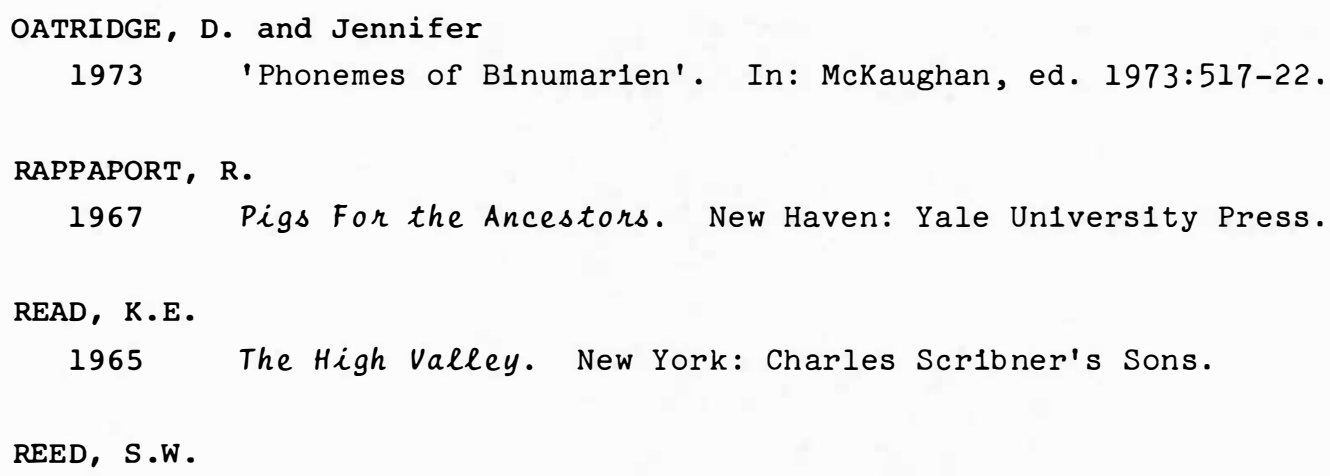

1968 Soc1al Aspects of Multilingualism in New Guinea. Ph.D. thesis, McGill University.

1969 'Mutual Intelligibility, B1lingualism and Linguistic Boundarles'. International Days of Sociolinguistics. Second International Congress of Soclal Sclences of the Lu1g1 Sturze Inst1tute. 839-48.

1976 'Political Power and Linguistic Inequality in Papua New Gulnea'. In: O'Barr, W. and J., eds. Language and Politics. 283-310. The Hague: Mouton. (= F1shman, J., gen.ed. Contributions to the Sociology of Language 10.)

1977 'Creolization and Syntact1c Change in New Guinea Tok P1sin'. In: Blount, B. and M. Sanches, eds. Sociocultural Dimensions of Language Change. 119-30. London and New York: Academ1c Press. 
SANKOFF, Gillian and Suzanne LABERGE

1973 'On the Acquisition of Native Speakers by a Language'. Kivung $6: 32-47$.

SCHLESIER, E. von

1961 Ü̈ber die Zweisprachigkeit und die Stellung der Zweisprachigen in Melanesien, besonders auf Neuguinea'. In: Beiträge zur Völkerforschung: Hans Damm zum 65. Geburtstag. 550-76. Le1pzig: Museum für Völkerkunde, Heft 11 .

SEBEOK, T.A., ed.

1971 Current Trends in Linguistics, vol. 8: Linguistics in oceania. 2 vols. The Hague: Mouton.

SELIGMAN, C.G.

1910 The Melanesians of British New Guinea. Cambridge University Press.

STRATHERN, Marilyn

1972 Women in Between. London and New York: Seminar Press.

WAGNER, R.

1969 'Marriage Among the Daribi'. In: Glasse, R.M. and M.J. Meggitt, eds. Pigs, Pearlshells, and Women. 56-76. New Jersey: Prentice-Hall.

WURM, S.A.

1960 'The Changing Linguistic Picture of New Guinea'. Oceania 31: $121-36$.

1961 Language Map of the Eastern, Western, and Southern Highlands, Territory of Papua New Guinea. PL, D-4.

1964 'Australian New Guinea Highlands Languages and the Distribution of Their Typological Features'. AmA 66/4, (2): 77-97.

1966 'Language and Literacy'. In: Fisk, E.K., ed. New Guinea on the Threshold. 135-48. Canberra: Australian National University Press. 
1966-67 'Papua-New Guinea Nationhood: The Problem of a National Language'. JPNGS 1/1:7-19.

1969 'English, Pidgin and What Else?'. New Guinea 4/2:30-42.

1971a 'The Papuan Linguistic Situation'. In: Sebeok, ed. 1971: 541-657.

1971b 'Pidgins, Creoles, and Lingue Franche'. In: Sebeok, ed. 1971:999-1021.

1971c New Guinea Highlands Pidgin: Course Materials. PL, D-3.

WURM, S.A., ed.

1975 New Guinea Area Languages and Language Study, vol.I:

Papuan Languages and The New Guinea Linguistic Scene. $P L, C-38$.

1976 New Guinea Area Languages and Language Study, vol. II: Austronesian Languages. PL, C-39.

WURM, S.A. and J.B. HARRIS

1963 Police Motu: An Introduction to the Trade Language of

Papua (New Guinea), For Anthropologists and other Fieldworkers. $P L, B-1$.

WURM, S.A. and D.C. LAYCOCK

1961 'The Question of Language and Dialect in New Guinea'. oceania $32: 128-43$.

WURM, S.A. and D.C. LAYCOCK, eds

1970 Pacific Linguistic Studies in Honour of Arthur capell. $P L, C-13$.

WURM, S.A., ed., with P. MÜHLHÄUSLER, D.C. LAYCOCK and T.E. DUTTON

1978 Handbook of New Guinea Pidgin. PL, C-48. In press.

Z'GRAGGEN, J.A.

1971 Classificatory and Typological Studies in Languages of the Madang District. PL, C-19. 

P A R T 7.2.

WRITING VERNACULARS AND VERNACULAR LITERACY 
